\title{
Evaluating the effectiveness of the customized Unna boot when treating patients with venous ulcers*
}

A avaliação da eficácia da bota de Unna artesanal no tratamento de pacientes portadores de úlceras venosas

\author{
Bruna Suelen Raymundo Luz ${ }^{1}$ \\ Dênia Amélia Novato Castelli Von Atzingen ${ }^{2}$ \\ Marcos Mesquita Filhó
}

\author{
Cristina Souza Araujo ${ }^{1}$ \\ Adriana Rodrigues dos Anjos Mendonça ${ }^{3}$ \\ Mauricéia Lins de Medeiros ${ }^{5}$
}

\begin{abstract}
BACKGROUND: Lower limb ulcers are a serious medical and socioeconomic problem throughout the world. One type of chronic wound of the lower extremities is the venous ulcer. Therapeutic methods for treating venous ulcer include the use of the Unna boot.

OвJестіves: To evaluate the effectiveness of the customized Unna boot in the treatment of venous ulcers and to monitor the subsequent development and healing of the lesions.

MEthoDS: Prospective exploratory and quantitative longitudinal study, conducted at the "Outpatients Department (Wound Care) of the Grupo da Fraternidade Espírita Irmão Alexandre" in the city of Pouso Alegre (MG), Brazil, in 2008. The sample consisted of 32 patients with venous ulcers who underwent treatment with the Unna boot and 11 patients (control group), who used a simple bandage application. The patients 'lesions were monitored over a three month period.

REsuLTs: The average age of the predominently female (65.1\%) patients was 61.88. From observing the differences in healing times at the three evaluation stages, it was clear that after the initial evaluation the wound area decreased in Groups 1 and 2 ( $p>0.05)$. ConCLUSION: The use of the customized Unna boot contributes to quicker healing. However, over a period of three months the simple bandage applications were seen to be just as effective as the Unna boot method.
\end{abstract}

Keywords: Compression bandages; Occlusive dressings; Wound healing

Resumo: FundAMENTOS: As úlceras de membros inferiores constituem um sério problema médico e socioeconômico mundial. Um tipo de ferida crônica dos membros inferiores é a úlcera venosa. Dentre os métodos terapêuticos encontra-se o curativo bota de Unna artesanal.

OBjetivos: Avaliar a eficácia do uso da bota de Unna artesanal no tratamento de úlceras venosas e acompanhar o desenvolvimento da cicatrização das feridas.

MÉToDos: Estudo do tipo longitudinal e prospectivo, de caráter exploratório e quantitativo, realizado no ambulatório de feridas do Grupo da Fraternidade Espírita Irmão Alexandre na cidade de Pouso Alegre - MG, no ano de 2008. A amostra foi composta de 32 pacientes portadores de úlceras venosas que realizavam o tratamento com bota de Unna e de 11, grupo controle, que utilizaram curativo simples. As lesões dos pacientes foram acompanhadas por um período de três meses.

RESultados: A idade média das pessoas foi de 61,88 anos, predominando o sexo feminino (65,1\%). Observando-se as diferenças nos tempos de cicatrização das feridas, em relação aos três momentos de avaliação, evidenciou-se que após a avaliação inicial houve diminuição da área da ferida, semelhante tanto para o grupo 1 como para o grupo 2 ( $\mathrm{p}>0,05)$.

CONCLUSÃo: A utilização da Bota de Unna artesanal contribui para aceleração no processo cicatricial, porém quando comparada com o curativo simples apresentou semelhante eficiência que este, quando analisada por um período de três meses.

Palavras-chave: Bandagens compressivas; Cicatrização; Curativos oclusivos

Received on 19.03.2012

Approved by the Advisory Board and accepted for publication on 251212.

* Study undertaken at the Faculty of Medicine of the Vale do Sapucai University (UNIVAS). Support for the Outpatients Department (Wound Care) of the Grupo da Fraternidade Espírita Irmão Alexandre - Pouso Alegra (MG), Brazil.

Financial support: none.

Conflict of interests: none.

Undergraduate medical student at the Vale do Sapuca University (UNIVAS) - Pouso Alegra (MG), Brazil.

Doctorate - Nurse and professor at the Vale do Sapuca University (UNIVAS) - Pouso Alegra (MG), Brazil.

Doctorate - Biomedic and Full Professor of Cell Biology of the Vale do Sapuca University (UNIVAS) - Pouso Alegra (MG), Brazil.

Doctorate - Doctor and Full Professor in the Management and Community Health Division of the Vale do Sapuca University (UNIVAS) - Pouso Alegra (MG), Brazil.

Doctorate - Nurse responsible for the Outpatients Department (Wound Care) of the Grupo da Fraternidade Espírita Irmão Alexandre - Pouso Alegra (MG), Brazil.

(C)2013 by Anais Brasileiros de Dermatologia 


\section{INTRODUCTION}

Leg ulcers are a serious medical and socio-economic problem worldwide. ${ }^{1}$ One type of chronic wound in the lower limbs is the venous ulcer, associated with high blood pressure, diabetes mellitus and chronic venous insufficiency in the lower legs. It has a high clinical incidence (between $80 \%-90 \%$ of all leg ulcers). ${ }^{2}$ Venous ulcers are most common in females $($ ratio $=2.6: 1)$. The incidence increases with age, affecting more than $4 \%$ of patients over $65 .{ }^{3,4}$

Clinical history, family history and physical examination should be the key elements for diagnosis. ${ }^{5}$ The main factors that trigger the ulcerations include trau$\mathrm{ma}$ in the lower legs, the presence of varicose veins and deep vein thrombosis (DVT). ${ }^{6}$

The etiology of venous ulcers is different from other leg ulcerations since they do not heal in six weeks and they are exudative and more superficial with irregular borders. They are common in the medial malleolus. One of the most prevalent symptoms is pain, which is not influenced by the ulceration size. The pain usually becomes worse at the end of the day in an orthostatic position and increases on lifting the leg. ${ }^{3,7}$

The principal therapeutic methods are compression therapy, local ulcer treatment, systemic medication and surgical treatment of the venous anomaly. 3 Several professionals suggest that compression therapy is sufficient to heal venous ulcers. ${ }^{8}$

The Unna boot is one compression therapy method. It is the most traditional and provides a semisolid mold acting as an effective compression device. Such non-elastic bandages provide high pressure when the muscles are contracted (e.g. when walking) and small pressure at rest. Patients feel comfortable using this kind of compression. Benefits include protection against trauma and minimal interference in daily activities. Disadvantages include pressure on the leg exerted over longer periods, the shortage of trained nurses and doctors familiar with application of the boot and the device's unsuitability for highly exudative wounds. ${ }^{3}$

The boot consists of a low compression gauze bandage (18-24 $\mathrm{mmHg}$ ) containing $10 \%$ zinc oxide paste, gelatin, glycerin and water. It was invented in 1896 by the German dermatologist Paul Gerson Unna. ${ }^{8}$ It adjusts to the leg, calf and foot even during muscle contraction, and can be purchased in stores or made at home with special materials. It needs changing every three to seven days, depending on the exudate and edema. This should be done by a nurse, doctor or a skilled family member. ${ }^{3,9}$ The Unna boot allows patients to carry out their normal daily activities since there is no need to stay in bed to facilitate venous return. ${ }^{10}$

The Unna boot is not suitable in cases of arterial or mixed ulcers, swelling, erythema and intense inflammaion in the ulceration area. This also applies to patients with uncontrolled diabetes mellitus, since it might result in loss of sensitivity, causing a new lesion in the diabetic foot. ${ }^{6}$

The present study evaluated the effectiveness of the customized Unna boot for treating venous ulcers, by monitoring the healing process and measuring progress of the wound diameter.

The Unna boot method is not well-known in Brazil and little has been recorded about it in the literature. This research was performed basically to help improve treatment for leg ulcers at the health clinic of the Grupo da Fraternidade Espírita Irmão Alexandre in Pouso Alegre. It is hoped that the study results will be shared with other professionals in Brazil, given that a substantial number of people in this country suffer from venous ulcers.

\section{MATERIALS AND METHODS}

This is a longitudinal and prospective study with an exploratory and quantitative approach.

\section{Study Field:}

The study was carried out in 2008 at the Outpatients Department (Wound Care) of the Grupo da Fraternidade Espírita Irmão Alexandre, Pouso Alegre, State of Minas Gerais Brazil.

\section{Study sample:}

The sample comprised 43 patients with venous ulcers (28 females and 15 males) aged between 25 and 82 being treated in the above Outpatients Department of the Grupo da Fraternidade Espírita Irmão Alexandre.

The sample was divided into two subgroups. The first included 32 patients who used a customized Unna boot as their treatment of choice and the second consisted of 11 patients using a simple bandage dressing (control group).

Patients were selected based on how often they were treated and their number of lesions (including patients with only one lesion). The control group sample was small because of the smaller number of patients using traditional dressings. The patients in the control group could not be treated with the Unna boot because they had swelling, erythema and/or extensive inflammation in the area. Compression in such cases would have increased the local wound, while the friction produced by the bandage over a long period would almost certainly increase the erythema without reducing inflammation. The boot is also counter-indicated in cases of uncontrolled diabetes mellitus, which could result in a new trauma due to sensitivity loss, causing a new lesion in the diabetic foot. ${ }^{6}$ 
Prior to selecting the type of bandage (boot or regular dressing) all patients at the clinic were required to follow the same procedures, such as cleaning the wounds with tap water, soap and sterile saline solution, applying sugar to the lesion and resting for 20 minutes with the legs up. The aim was to produce more reliable comparative data for the purposes of the study (Figure 1).

\section{Tools for collecting data:}

Data were collected using an interview questionnaire and a form for the physical examination, adapted to the patients ${ }^{-}$particular condition. ${ }^{11}$

\section{Data analysis and collection:}

All patients were informed about the present study and all concurred with the rules. After signing the free informed consent form, an initial interview was conducted with patients to acquire information on items such as socio-economic background, habits and clinical history.

Periodic evaluation of the lesion included completing a physical exam form containing information on vital signs, peripheral pulses and lesion measurement.

Patients retured to the clinic once a week to have their bandages changed. The procedures in the evaluated patients were the following:

1) Removal of the Unna boot or simple dressing:

The wound was first cleaned with cold water to remove the gauze used in the old dressing.

2) Wound measurement:

Wound measurement was performed along the

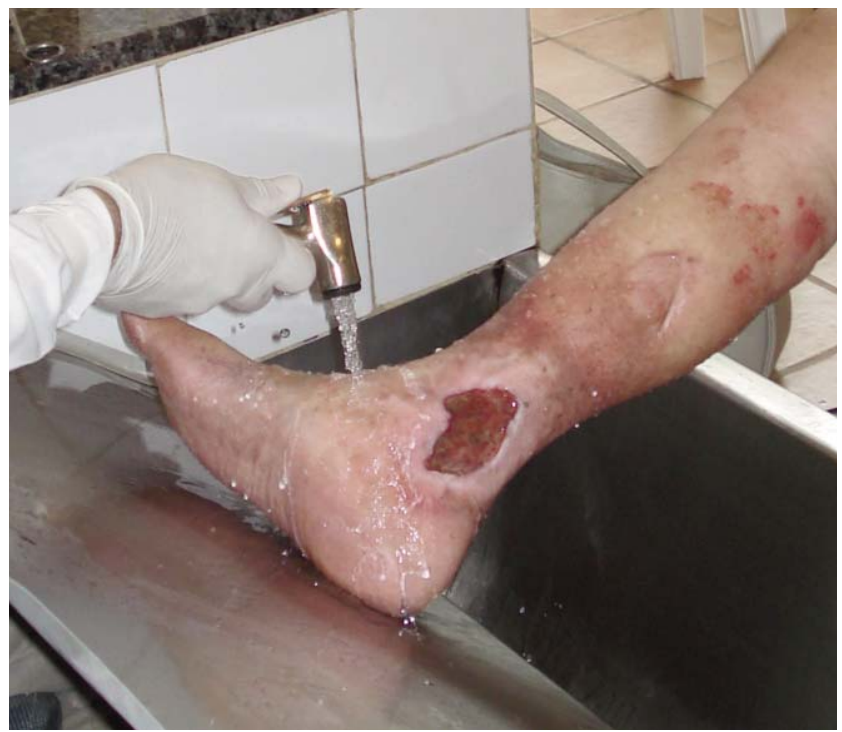

Figure 1: Cleaning the ulcer with running water contour edge using two non-sterilized plastic layers, where only one layer touched the wound bed before being discarded. A special pen was used to draw the contour. Patients were identified by their initials. The affected member, type of dressing, date of data collection and number of measurement were recorded, together with photographs of the ulcer or ulcers. A value equal to the area of the ulceration (s) was found by multiplying the greatest horizontal and vertical measurement (Figure 2).

3) Wound cleansing using tap water, soap and saline solution:

The wound was cleaned for the second time with cold water to remove superficial debris in the leg. Along with the mechanical cleansing with gauze, coconut soap was used and the wound rinsed with a warm $0.9 \%$ sodium chloride solution.

4) Use of sugar in the wound area; angle;

5) Twenty-minute rest with legs at a $45^{\circ}$ sugar;

6) Use of saline solution to remove the

7) Use of a regular dressing or Unna boot.

A simple dressing was made by using a collagenase-based ointment, gauzes, bandage and tape. Patients were instructed to change the dressing daily.

In order to prepare 1 liter of Unna paste, $360 \mathrm{~g}$ of white gelatine should be dissolved in warm water, simmering the solution for 12 hours. Add $360 \mathrm{ml}$ of glycerin, $360 \mathrm{ml}$ of meshed zinc oxide and $360 \mathrm{ml}$ of distilled water. Let it cool in a stainless steel tray.

Before applying the Unna boot, sterile gauzes embedded in Vaseline should be placed on the wound. Begin wrapping the leg in an upward direc-

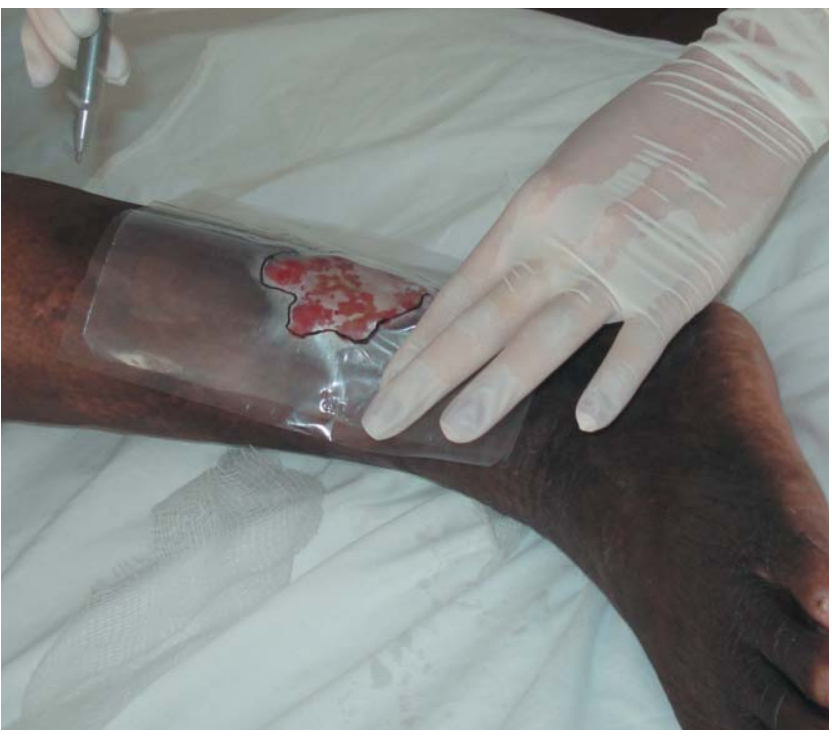

Figure 2: Measuring the area of the ulcer 
tion, starting above the toes and proceeding up to the knee, with each layer overlapping the other firmly but not too tightly (Figure 3 ). To maintain this perfectly over the contour of the leg, the bandage has to be cut as often as needed. The Unna paste is melted in a hotwater bath (for about 15 minutes ) before being embedded in the bandage. The device can then be applied like a plaster cast to the leg until it dries in roughly 5 minutes. The boot needs to kept in place for seven days and protected in the shower.

Data were collected for three months and each wound measured every month. The wound drawings and measurements were attached to each patient's physical exam notes. The measurements were transcripted after the size of the area of each wound was calculated, and all the areas in the affected limb were added. The photos were downloaded to a computer and placed in separate files for each patient, including the number of wound measurements.

\section{RESULTS}

The study included two groups: one comprising 32 patients (74.4\%) with venous ulcers and aged over 30 who were treated with the Unna boot (Group 1) and 11 patients (25.6\%) treated with a simple dressings served as the control group.

\section{Descriptive Statistics ${ }^{12}$}

The mean age of patients was 61.88 years, with females in the majority (65.1\%).

Average years of education was 4.09 years. $28.6 \%$ of the patients had never attended school at any time. The average per capita income was $R \$$ 313,79 .

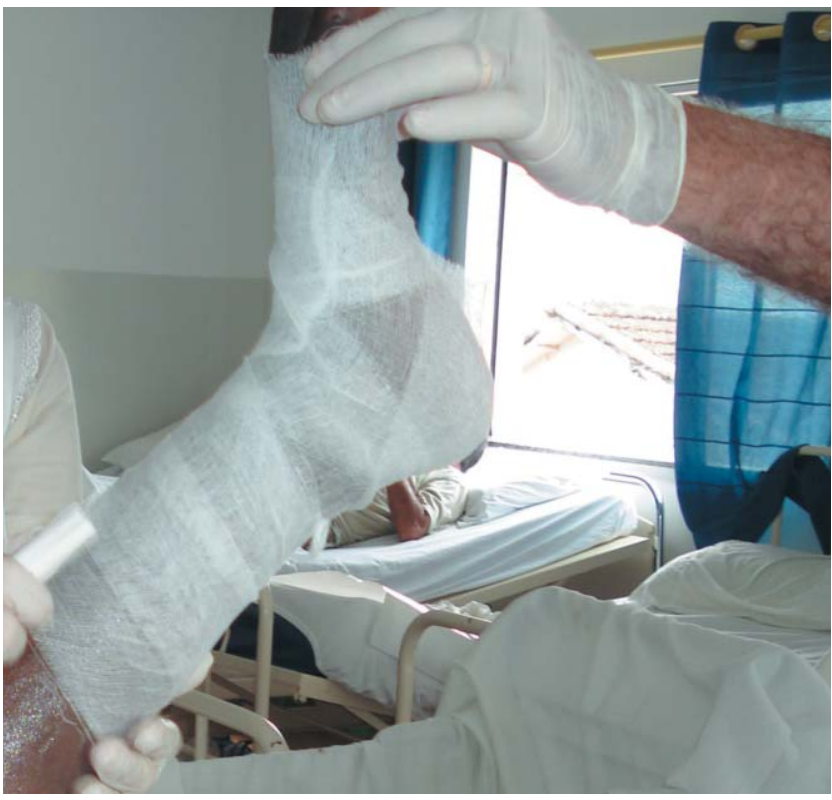

FigURE 3: Applying dressing prior to positioning the Unna paste boot
We observed that $92.3 \%$ and $97.4 \%$ of the patients respectively, were not habit dependent and did not smoke or drink alcohol. Regarding the clinical variables patients exhibited a high incidence of arterial hypertension (56.4\%). 20.5\% of the patients had diabetes mellitus.

When evaluating the duration of the wound, we noted a wide variation - from 6 months to 44 years. During the physical exam, the average systolic blood pressure was $133.13 \mathrm{mmHg}$, diastolic pressure 82.6 $\mathrm{mmHg}$ and pulse $72.9 \mathrm{bpm}$.

1.a. Comparison of the qualitative and quantitative variables in the two study groups

The purpose of this comparison was to verify if there were differences between the groups. The chisquare or Fisher's exact test to compare the groups was used when necessary. A significance level of 5\% was established for the test. When the p-value was less than 0.05 , the difference was considered as statistically significant.

According to the results shown in table 1, the only differences concerned the presence of DM $(p<0.05)$, indicating a higher percentage of patients with diabetes in the control group (Group 2).

The Student's t-Test was used to compare the quantitative variables between the two groups, also considering a significance level of 5\%.

Based on the results shown in table 1 , no statistically significant difference was found for the variables between the two groups ( $p>0.05)$.

\section{Statistical Analysis}

Comparing the wound between the groups over time

In this phase of the study the aim was to compare the average results found between the groups (called 'group effect') while drawing a comparison at three different evaluation times ('time effect'). We used the Repeated Measures ANOVA statistical test to compare the groups at different times. ${ }^{13}$ The repeated measures test was used because the measurements over time were taken from the same individual. In order to use this approach, the covariance matrix of observations of a same individual needed to have a specific form, failing which the tests were corrected using the Huynh-Feldt correction. Table 2 shows the results of all the tests, indicating differences between the groups or among the different periods of time when the value of $p<0.05$. The study also assessed whether an interaction existed in the results, revealing different behavior due to another variable. Such an interaction might indicate that the groups present different behaviors at a specific observed moment and possible time differences for certain groups. No interaction effect was in fact observed in the tests performed when the comparisons were made $(p>0.05)$. 
TABLE 1: Comparison of qualitative and quantitative variables between the two study groups

\begin{tabular}{|c|c|c|c|c|c|c|}
\hline & \multicolumn{2}{|l|}{ Qualitative } & \multicolumn{3}{|l|}{ Group } & \multirow{3}{*}{ p-value } \\
\hline & & \multicolumn{2}{|l|}{ Group 1} & \multicolumn{2}{|l|}{ Group 2} & \\
\hline & & $\mathbf{n}$ & $\%$ & $\mathbf{n}$ & $\%$ & \\
\hline \multirow[t]{2}{*}{ Sex } & Male & 12 & $37.5 \%$ & 3 & $27.3 \%$ & $0.719(\mathrm{~F})$ \\
\hline & Female & 20 & $62.5 \%$ & 8 & $72.7 \%$ & \\
\hline \multirow[t]{3}{*}{ Education } & Never studied & 7 & $28.0 \%$ & 3 & $30.0 \%$ & 0.766 \\
\hline & $>5$ years yearsanos & 13 & $52.0 \%$ & 4 & $40.0 \%$ & \\
\hline & $<5$ years & 5 & $20.0 \%$ & 3 & $30.0 \%$ & \\
\hline \multirow[t]{2}{*}{ DM } & No & 26 & $89.7 \%$ & 5 & $50.0 \%$ & $0.016(\mathrm{~F})$ \\
\hline & Yes & 3 & $10.3 \%$ & 5 & $50.0 \%$ & \\
\hline \multirow[t]{2}{*}{ AH } & No & 14 & $48.3 \%$ & 3 & $30.0 \%$ & $0.464(\mathrm{~F})$ \\
\hline & Yes & 15 & $51.7 \%$ & 7 & $70.0 \%$ & \\
\hline \multirow[t]{2}{*}{ Drinking } & No & 28 & $96.6 \%$ & 10 & $100.0 \%$ & $* * *$ \\
\hline & Yes & 1 & $3.4 \%$ & & & \\
\hline \multirow[t]{5}{*}{ Smoking } & No & 26 & $89.7 \%$ & 10 & $100.0 \%$ & $0.556(\mathrm{~F})$ \\
\hline & Yes & 3 & $10.3 \%$ & & & \\
\hline & \multirow[t]{3}{*}{ Qualitative } & & Group & & & \\
\hline & & Group 1 & & Group 2 & & p-value \\
\hline & & $\mathbf{n}$ & 32 & 11 & & \\
\hline \multirow{6}{*}{\multicolumn{2}{|c|}{ Systolic arterial pressure-average $(\mathrm{mmHg})$}} & & & & & 0.134 \\
\hline & & average & 131.06 & 139.15 & & \\
\hline & & median & 130.5 & 145 & & \\
\hline & & st.deviation & 14.39 & 17.23 & & \\
\hline & & minimum & 102 & 110 & & \\
\hline & & maximum & 167 & 173.3 & & \\
\hline \multirow{6}{*}{\multicolumn{2}{|c|}{ Diastolic arterial pressure-average (mmHg) }} & & 0.503 & & & \\
\hline & & average & 83.19 & 81.13 & & \\
\hline & & median & 82.65 & 80 & & \\
\hline & & st.deviation & 8.38 & 9.7 & & \\
\hline & & minimum & 63 & 70 & & \\
\hline & & maximum & 100 & 106.7 & & \\
\hline \multirow{6}{*}{\multicolumn{2}{|c|}{ Average pulse (rpm) }} & & 0.509 & & & \\
\hline & & average & 73.28 & 71.83 & & \\
\hline & & median & 72.5 & 70 & & \\
\hline & & st.deviation & 5.98 & 6.93 & & \\
\hline & & minimum & 63 & 65 & & \\
\hline & & maximum & 84.7 & 85 & & \\
\hline \multirow{6}{*}{\multicolumn{2}{|c|}{ Duration of lesion (months) }} & $\mathrm{n}$ & 24 & 10 & 0.141 & \\
\hline & & average & 211.8 & 122.6 & & \\
\hline & & median & 186 & 48 & & \\
\hline & & st.deviation & 157.4 & 155.0 & & \\
\hline & & minimum & 6 & 6 & & \\
\hline & & maximum & 528 & 480 & & \\
\hline
\end{tabular}


TABLE 2: Comparison of wound over time between the groups: area in $\mathrm{cm}^{2}$

\begin{tabular}{|c|c|c|c|c|}
\hline & & $\operatorname{Area} 1\left(\mathrm{~cm}^{2}\right)$ & Area $2\left(\mathrm{~cm}^{2}\right)$ & Area $3\left(\mathrm{~cm}^{2}\right)$ \\
\hline \multirow[t]{6}{*}{ Group 1} & $\mathbf{n}$ & 32 & 32 & 32 \\
\hline & average & 15.25 & 11.8 & 9.38 \\
\hline & median & 4.8 & 2 & 1.35 \\
\hline & st.deviation & 27.17 & 20.68 & 15.57 \\
\hline & minimum & 0.5 & 0 & 0 \\
\hline & maximum & 121.6 & 81 & 56.7 \\
\hline \multirow[t]{6}{*}{ Group 2I } & $\mathbf{n}$ & 11 & 11 & 11 \\
\hline & average & 28.23 & 20.13 & 20.29 \\
\hline & median & 10.2 & 9.6 & 6.6 \\
\hline & st.deviation & 29.82 & 23.73 & 29.43 \\
\hline & minimum & 2.8 & 0 & 0 \\
\hline & maximum & 83.6 & 65.1 & 80.4 \\
\hline
\end{tabular}

Interaction effect - $\mathrm{p}=0,454$

Time effect (moments 1,2 and3) - p=0,007

Moments $1 \times 2-\mathrm{p}=0,003$

Moments $1 \times 3-\mathrm{p}=0,041$

Moments $2 \times 3-\mathrm{p}>0,999$

Group effect (Group 1 and Group 2) - p=0,177

TABLE 3: Comparison of wound over time between the groups:area in percentages

\begin{tabular}{llll}
\hline & & Area 2 (\%) & Area 3 (\%) \\
\hline Group 1 & n & 32 & 32 \\
& average & -33.65 & -44.9 \\
& median & -35.41 & -47.12 \\
& st.deviation & 48.12 & 58.48 \\
& minimum & -100 & -100 \\
Group 2 & maximum & 77.78 & 107.41 \\
& n & 11 & $\mathbf{1 1}$ \\
& average & -29.18 & -43.45 \\
& median & -22.05 & -53.06 \\
& st.deviation & 39.74 & 57.8 \\
& minimum & -100 & -100
\end{tabular}

Interaction effect - $\mathrm{p}=0,818$

Time effect (moment1,2 and3) - $\mathrm{p}=0,057$

Group effect (Group 1 and Group 2) $\mathrm{p}=0,864$

The Bonferroni test was used when the comparisons of the main effects were made to identify which items showed significant differences, also including the difference when $\mathrm{p}<0.05$ (Table 2).

Graphs 1 and 2 were constructed in order to provide the best interpretation of these results.

\section{Area in centimeters}

According to the results shown in table 2, we observed that there was only a difference between the moments, regardless of the group. Multiple comparisons were made to identify which group was different.
When observing the differences in the wound healing time based on the three different times of evaluation, the average area in Group 1 was respectively 15.25, 11.8 and $9.38 \mathrm{~cm}^{2}$. In Group 2, the average areas were $28.23,20.13$ and $20.29 \mathrm{~cm}^{2}$, respectively.

\section{Multiple comparisons between moments}

After performing the multiple comparisons, a difference between moment 1 and the other moments was observed $(\mathrm{p}<0.05)$, showing that after the initial evaluation the wound area decreased (Table 2). This kind of behavior was similar both for Groups 1 and 2 . 


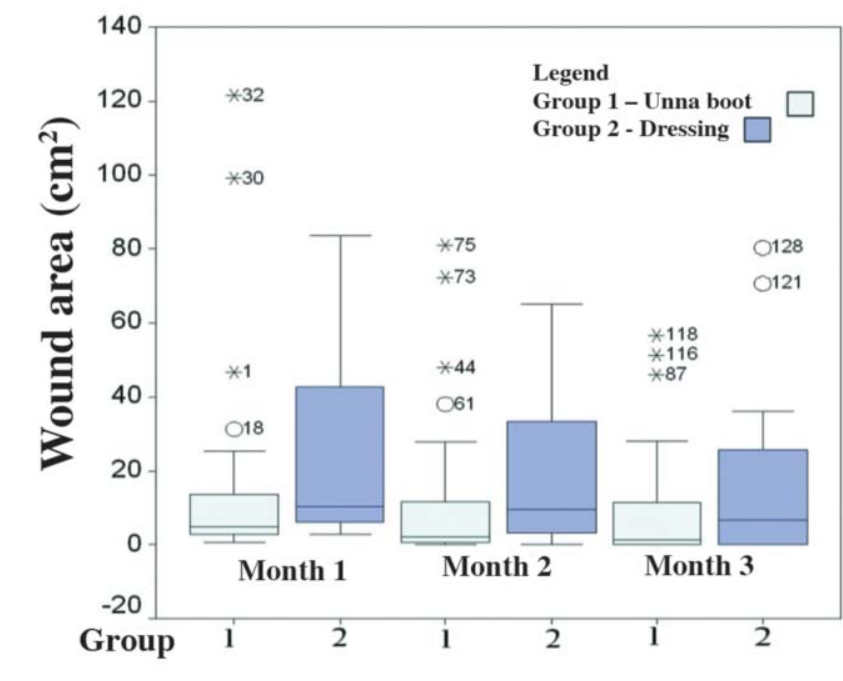

GRAPH 1: Comparison of area of wound over time in $\mathrm{cm}^{2}$

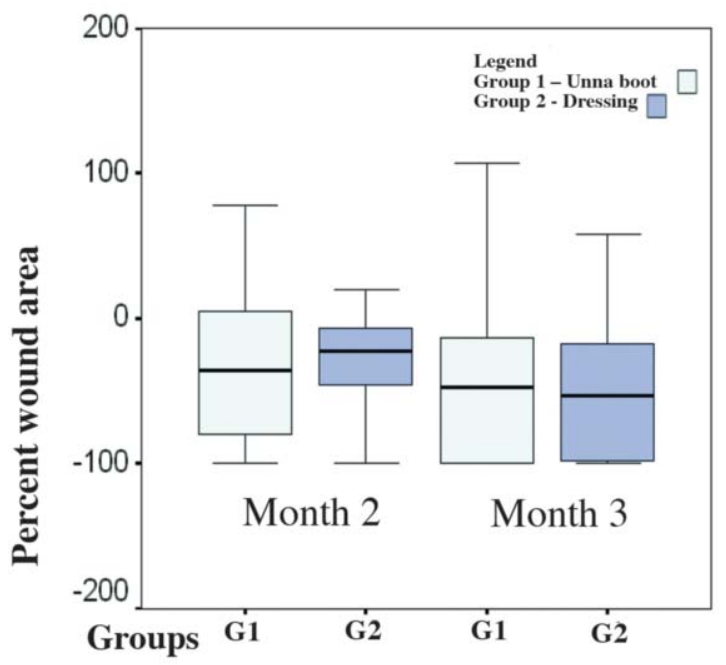

GRAPH 2: Comparison of percentage area of wound over time

Graphs 1 and 2 illustrate these results.

\section{Percentage Area}

The initial measurement (Area 1) was excluded from the analysis (100\%) in table 3 in order to compare percentage decrease.

No difference was observed between the moments or groups ( $p>0.05)$. Graphs 1 and 2 illustrate these results.

\section{DISCUSSION}

Venous ulcers are a serious public health problem, with thousands of patients seeking help from outpatient clinics and other public health facilities.

The prevalence of venous ulcers increases with age, being more common among people in the 60-80 age bracket. ${ }^{14}$ In the present study the mean age in the sample was 61.88 , similar to the sample studied by Frade et al, where the mean age was 64 , with a population of mainly over 60 -year olds (59\%). ${ }^{15}$ The link between aging and ulcers might be explained by venous system malfunction which is common among the elderly. ${ }^{15}$

As for gender, of the 43 patients included in the present study, ulcers were observed mainly in the female contingent $(65.1 \%)$. According to Koksal \& Bozkurt, this phenomenon was often found in the literature and might be explained by the fact that women have a certain predisposition to varicose veins. ${ }^{16}$ Hormonal reactions during pregnancy, the menstrual cycle and the menopause seem to be associated with greater vein enlargement than in males. Hormone therapy and birth control pills also increase the risk of varicose veins. Some researchers argue that the main initial cause of varicose veins among young adults derives from the use of birth control pills. ${ }^{17}$

Regarding ulcer chronicity, the mean duration was 211.8 months in patients treated with the Unna boot and $\mathbf{1 2 2 . 6}$ months in the group using a simple dressing. These results show a longer mean time compared to the study by Frade et al., where the ulcers healed after 94 months. ${ }^{15}$

We observed that the treatment of venous ulcers requires lengthy follow-up, resulting in physical, functional, emotional and financial problems for the patients. Moreover, this chronicity results in substantial public health expenditure and evident social and economic impacts. ${ }^{3,4}$

The association between a chronic venous insufficiency and systemic arterial hypertension found in this study was not significant. This was probably due to the difficulty faced by the researchers when collecting data in this particular health facility, where the shortage of reliable records meant that the study was confined to patients' medical history. In the Frade et al. study a key association was found between chronic venous insufficiency and systemic arterial hypertension in $43.7 \%$ of the population studied $(\mathrm{p}<0.01){ }^{15}$ This study also reveals that this type of association emphasizes the importance of controlling and/or treating chronic venous insufficiency, arterial hypertension, and other risk factors such as diabetes mellitus. ${ }^{18}$ Our study found a higher percentage of patients with diabetes mellitus in the control group (Group 2), perhaps explained by the contraindicated use of compression methods in diabetic patients which could cause new lesions in the diabetic foot. ${ }^{6}$ On the other hand, diabetic patients who used the Unna boot as 
their method of choice had good glycemic control.

Wound development was monitored by measuring the wound over three consecutive months and analysed on a monthly basis. Wound size can be analyzed in several ways. The most common method is to use a ruler to measure the biggest and smallest area and calculate the size of the flat surface according to the shape of the ulcer. Because the ulcer contour is not precise this method was however only used when the wounds possessed a regular shape..$^{19,20}$

After three months data collection, based on the multiple comparisons, a difference between the first moment (first month) and the other moments ( $2^{\text {nd }}$ and 3 rd month $)(p<0.05)$ was found, indicating that following the first evaluation the ulcer actually decreased. No significant difference was found between Group 1 (Unna boot) and Group 2 (simple dressing) (Figure 4).

The similar healing rate between the 2 groups does not accord with findings in the literature, probably explained by the difficulty we encountered in collecting data from absentee patients at the clinic, which prevented us from securing a more representative and homogenous sample in the two groups.

Cullum et al. have reported that the best healing rate was obtained with the use of a high compression $(40 \mathrm{mmHg})$ rather than a low compression bandage. ${ }^{21}$ These authors also argue that a high graduated compression with a multilayer system able to sustain the compression $(40 \mathrm{mmHg})$ should be used at least once a week as the first choice of treatment by patients with non-complex venous ulcers.

Borges et al. suggest that the compression treatment increases the healing rate of venous ulcers when compared to treatment with no compression, resulting in cost effective and reliable healing in the majority of patients. ${ }^{18}$

Certain other studies analyze compression treatments. Cordts et al. for example compared the DuoDERelastic compression (a hydrocolloid dressing) with the Unna boot and failed to find differences of healing rates over 12 weeks. ${ }^{22}$

Several authors advocate the use of compression methods such as the Unna boot not only because of its effective healing properties but also because of the lower costs involved. ${ }^{21,23}$

The cost of cleansing and compression therapies in terms of the Unna boot treatment is lower than the final cost of treatment with traditional dressings. Unna boot treatment also provides more comfort for the patient due the need to change dressings less frequently (generally only once or twice a week) and accelerates the healing process, resulting overall in lower costs. Traditional treatment requires dressings to be changed daily. In the present study we were not
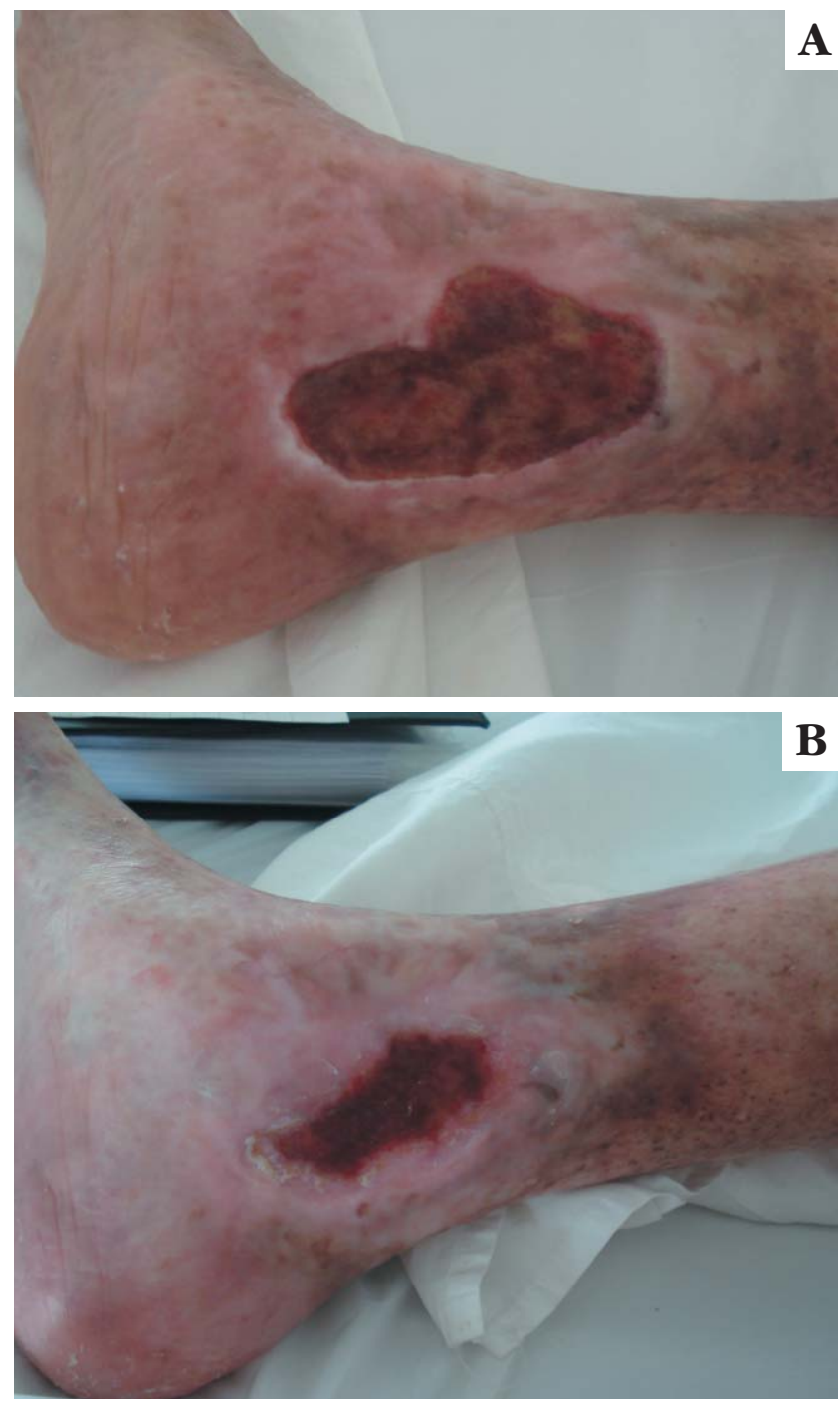

FIGURE 4: A. First month of evaluation of progress of healing the ulcer of a patient using the Unna boot; $\mathbf{B}$. Third month of evaluation of progress of healing the ulcer of a patient using the Unna boot

able however to make a valid costs comparison between the two methods.

Partsch et al. have showed that one of the disadvantages of compressive therapy is that the Unna boot does not adapt to changes in leg volume. ${ }^{24} \mathrm{~A}$ further problem according to them is that treatment depends on the level of compression obtained.

The presence of a multidisciplinary team and the cooperation of patients are essential for treating venous ulcers. ${ }^{21}$ All the professionals involved need to possess up-to-date clinical knowledge of this subject. ${ }^{25}$ It is also worth noting that wound healing often does not depend on the type of dressing used, but rather on the role played by the patient in controlling the venous hypertension and healing process. ${ }^{3}$ Furthermore, a number of other factors may need to be taken into consideration when treating cases of 
venous ulceration, including, for example, a patient's inadequate nutritional status, psychological health, adjacent infections, uncontrolled chronic diseases and wound chronicity. ${ }^{26,27}$

Other studies are called for to describe and quantify further the population treated with the customized Unna boot.

\section{CONCLUSION}

The use of the Unna boot accelerated healing times. Over three months however the traditional method was observed to be just as effective.

\section{REFERENCES}

1. Bergonse FN, Rivitti EA. Avaliação da circulação arterial pela medida do índice tornozelo/braço em doentes de úlcera venosa crônica. An Bras Dermatol. 2006;81:131-5.

2. Guimarães Barbosa JA, Nogueira Campos LM. Diretrizes para o tratamento da úlcera venosa. Enferm Glob. 2010;20:1-13

3. Abbade LPF, Lastória S. Abordagem de pacientes com úlcera da perna de etiologia venosa. An Bras Dermatol. 2006;81:509-22.

4. Baptista CMC, Castilho V. Cost survey of procedure with Unna boot in patients with venous ulcer. Rev Latino Am Enferm. 2006;14:944-9

5. Aguiar ET, Pinto LJ, Figueiredo MA, Savino NS. Úlcera de insuficiência venosa crônica. Diretrizes sobre diagnóstico, prevenção e tratamento da Sociedade Brazileira de Angiologia e Cirurgia Vascular (SBACV). J Vasc Bras. 2005;4(Supl.2):S195-200.

6. Brazil. Ministério da Saúde. Secretaria de Políticas de SaúdeManual de condutas para úlceras neurotróficas e traumáticas.Brasília: Ministério da Saúde; 2002. 56 p.

7. Yamada BFA. Úlceras venosas. In: Jorge AS, Dantas SRPE. Abordagem multiprofissional do tratamento de feridas. São Paulo: Atheneu; 2003. p.247-59.

8. Borges EL. Tratamento tópico de úlceras venosas: proposta de uma diretriz baseada em evidências [tese]. Ribeirão Preto (SP): Universidade de São Paulo; 2005. 305 p.

9. Lopes AR, Aravites LB, Lopes MR. Úlcera venosa. Acta Médica de Porto Alegre. 2005;26:331-41.

10. Moreira JW. Utilidade da Bota de Unna no tratamento de úlceras de estase venosa nos pacientes atendidos no ambulatório do anexo de dermatologia do Hospital das Clínicas da Universidade da Universidade Federal de Minas Gerais [tese]. Belo Horizonte (MG): Universidade Federal de Minas Gerais; 2001.78 p.

11. Borges EL. Limpeza e desbridamento. In: Borges EL, Saar SRC, Magalhães MBB, Gomes FSL, Lima VLAN. Feridas: como tratar. 2. ed. Belo Horizonte: COOPMED; 2008. p.113-32

12. Magalhães MN, Lima ACP. Noções de probabilidade e estatística. 2. ed. São Paulo: IME- USP; 2000.

13. Neter J, Kutner MH, Nachtsheim CJ, Wasserman W. Applied linear statistical models. 4.ed.Chicago: Times Mirror Higher Education Group; 1996.

14. Freitas MAS, Julião MCC. Transversal escharotomies: a new surgical technique adjuvant in the treatment of chronic ulcers with non-arterial etiology in the lower limbs. Acta Cir Bras. 2006;21(Supl4):84-8.

15. Frade MAC, Cursi IB, Andrade FF, Soares SC, Ribeiro WS, Santos SV, et al. Úlcera de perna: um estudo de casos em Juiz de Fora-MG (Brazil). An Bras Dermatol. 2005; 80:41-6.

16. Koksal C, Bozkurt AK. Combination of hydrocolloid dressing and medical compression stockings versus Unna's boot for the treatment of venous leg ulcers. Swiss Med Wkly. 2003;133:364-8.

\section{ACKNOWLEDGMENTS}

Our sincere thanks for the support provided by the following, without whom this study would have not been possible:

- Our teacher and friend Marcos Mesquita Filho of UNIVAS;

- Our friend Lucilene Marques, UNIVAS librarian;

- The "Grupo da Fraternidade Espírita Irmão Alexandre”, Pouso Alegre (MG).
17. Maffei FHA, Lastória S, Yoshida WB, Rollo HA, Giannini M, Moura R.Doenças vasculares periféricas. 4. ed. Rio de Janeiro: Guanabara; 2008.

18. Borges EL, CaliriMHL, Haas VJ. Systematic review of topic treatment for venous ulcers. Rev Latino-Am Enf. 2007;15:1163-70.

19. Dealey C. Cuidando de feridas: um guia para enfemeiras. São Paulo: Atheneu; 2001

20. Vowden K. Medição de feridas e úlceras. Nursing. 1996;98:31-3.

21. Cullum N, Nelson EA, Fletcher AW, Sheldon TA. Compression for venous leg ulcers. Cochrane Database Syst. 2003;CD000265.

22. Cordts PR, Hanrahan IM, Rodrigues AA, Woodson J, La Marte WW, Menzaion JO. A propestive randomizes Trial of Unna's boot versus duoderm CGF hydroactive dressing plus compression in the management of venous ulcers. J Vasc Surg. 1992;15:480-6.

23. Guest M, Smit5h JJ, Sira MS, Madden P, Greenhalgh RM, Davies H. Venous ulcer healing by four-layer compression bandaging is not influenced by the pattern of venous incompetence. Br J Surg. 1999;86:1437-40.

24. Partsch H, Damstra RJ, Tazelaar DJ, Schuller-Petrovic S, Velders AJ, de Rooij MJ, et al. Multicentric, randomized controlled trial of four-layer bandaging versus shortstretch bandaging in the treatment of venous leg ulcers. Vasa. 2001;30:108-13.

25. Ferreira AM, Andrade D. Swab de feridas: recomendável? Rev Enf UERJ. 2006; $14 ; 440-6$

26. Bajay HM, Pedrosa MMO, Lourenço MTN, Cortez SL, Paula MAB. Registro de avaliação e evolução de feridas: subsídios para reflexão e mudanças. Rev Estima. 2003;1:20-9.

27. Orosco SS, Martins EAP. Avaliação de feridas: uma descrição para sistematização da assistência. Enfermagem Brazil. 2006;5:39-47.

\author{
MAILING ADDRESS: \\ Bruna Suelen Raymundo Luz \\ Avenida Cel. Alfredo Custódio de Paula, 320 . \\ Medicina. \\ 37.550-000 Pouso Alegre, MG. Brazil \\ E-mail:brunaluz04@botmail.com
}

How to cite this article: Luz BSR, Araujo CS, Atzingen DANCV, Mendonça ARA, Mesquira Filho M, Medeiros ML. Evaluating the effectiveness of the customized Unna boot when treating patients with venous ulcers. An Bras Dermatol. 2013;88(1):41-9. 